\title{
Innovative Scenarios in the Teaching and Learning Process: A View From the Implementation of Virtual Platforms
}

\author{
Heriberto González Valencia ${ }^{1}$, Jakeline Amparo Villota Enríquez ${ }^{1} \&$ María Eufemia Freire Tigreros $^{1}$ \\ ${ }^{1}$ Education Faculty, Santiago de Cali University, Cali, Valle, Colombia \\ Correspondence: Heriberto González Valencia, Education Faculty, Santiago de Cali University, Cali, Valle, \\ Colombia. Tel: 57-313-720-7896. E-mail: hery77@hotmail.com
}

Received: April 1, 2018 Accepted: June 19, 2018 Online Published: June 21, 2018

doi: 10.5539/elt.v11n7p131 URL: http://doi.org/10.5539/elt.v11n7p131

\begin{abstract}
In this research article an analysis and evaluation of virtual learning spaces is carried out. To address this process, three (3) academic virtual platforms were selected, Moodle, Blackboard and Jimdo. The methodology used was of a descriptive type, applying the synchronous and asynchronous methods of virtual teaching established in each of the Institutions. A description and evaluation of each virtual platform was carried out taking into account four identified criteria: the technical and material design; instructional design; tutorial action and the virtual class. The evaluation using educational platforms generated scenarios of innovation from the social view since it allowed both the teacher and student to rethink the evaluation not only as an instrument but as a transversal process linked to different fields such as: social, cultural, economic, etc.
\end{abstract}

Keywords: virtual learning, virtual platforms, tutorial action, innovative scenarios

\section{Introduction}

Currently, we are immersed in different changes produced by the speed in which technology advances within society. There are continuous changes through the construction processes of different elements that we implement in our daily tasks, such as: the telephone, appliances, and books, among others (Enríquez \& Enríquez, 2018). Consequently, Gonzalez (2015) mentions that the impact of technology is visible not only in commerce, business and science but education is one of the fields most permeated by the phenomenon of technology. The quality of the teaching-learning process will always be linked to the transformation (Valencia, Enriquez, \& Acosta, 2018).

In this sense, the interest in conducting this study focuses on the use and / or implementation of different educational virtual platforms within B-learning classes; generating the integration of face-to-face classes with virtual educational tools such as, the virtual educational platforms where the ICTs are integrated with the different curricular contents. Valencia, Enriquez and Agredo (2017) said that virtual education platforms have become a high-quality complement to educational processes, integrating them academically allows obtaining significant achievements and increases innovation.

Thus, to carry out this study, three virtual educational platforms were selected. In the first one, the use of the Moodle platform is proposed, where within an assigned course, different tools are implemented, such as: people (students and professor), administration, messages, calendar, course information, activity agenda, description of activities, communication, support resources, teaching team among others. In the second one, the Blackboard platform was implemented, which, upon entering, it shows general interesting advertisements and the courses in which the students were enrolled, they find a design that offers tools such as the calendar, announcements, and emails. Being in the course the information of the platform becomes more specific, keeping the simplicity of the white and blue design, where links with the personal information of the user, information of the course, the institution and the educational community in general are offered. In the third one, the Jimdo educational virtual platform is implemented, this space presents a diversity of tools for the students, such as videos, links, and easily accessible books and, above all, the Integral Course Plan -ICP, which describes all the activities and tutorials to be carried out.

Therefore, this study consisted of analyzing educational virtual platforms, where they were initially characterized and then evaluated using different criteria such as: technical design, materials design, instruction design; tutorial 
action and the virtual class.

\subsection{Educational Virtual Platforms in Virtual Learning Spaces: A Perpective From the Evaluation Processes}

The continuous changes that have arisen in the world and in modern society in relation to technology are related to technological development, generating new spaces of communication and therefore ways of investigating, interacting, sharing and representing the world in different ways (Bustos \& Coll, 2010; Díaz, 2005). Consequently, these changes related to the technology surrounding society overturns multiple fields such as: Political, environmental, educational among others; particularly in the field of education, these changes linked with technology, try to support the teaching and learning process through technological tools such as virtual educational platforms.

In education, the linkage of new technologies has been possible thanks to the use of the internet, specifically the www (World Wide Web) has allowed the articulation of face-to-face education with integrated elements to online aids in its various forms such as B- Learning, E-Learning among others. Today there are many studies or distance learning centers designed at all levels and types of education (Elementary, secondary, higher education among others). The purpose of the integration of technology in the educational field is to strengthen the learning process of students, so that integrating and / or using the different virtual spaces in the learning process is an alternative that the professor has in the pedagogical practice. According to Enriquez, De Oliveira, and Valencia (2017) the process of reflection by professors regarding the integration of pedagogical tools is important for the student's learning process.

The virtual educational platforms are linked to the content that you want to teach about certain topics; however, they try to promote the relationship between the content and the way of approaching them using the elements immersed in our current society; that is, using those technological tools such as the computer, cell phone, tablet, etc. beyond a mere communication that can often remain in a "communication of friends or family", generating the link of these elements in the teaching and learning process with clear purposes established by the professor.

Given the above, countries and organizations establish ways of work that aim to achieve better educational achievements based on real changes and transformations that result in the quality of educational processes (Biggs, 2005). It is from this that educational virtual platforms emerge as new scenarios, where students and professors interact in different ways, thus allowing the development of new competences in students.

On the other hand, one of the aspects to take into account is the evaluation that should be established on the use and implementation of virtual educational platforms in the teaching and learning process, which is related to criteria that are established through a didactic contract where the student and professor are the protagonists of it.

In this study, the evaluation that was built from the valoration process on the educational virtual platforms where an adaptation of the different criteria was made in each of them, resulting in some guidelines that will serve as a guide for this process. Consequently, it will be reflected from three virtual platforms, which are understood as tools that give new meanings to learning as they contain codes, languages and symbols that determine meanings and ways of seeing the world different from traditional ones (Díaz, 2005; Moral \& Villalustre, 2009; Abarca, 2009; Bustos \& Coll, 2010).

The first criteria established is the technical design and the materials. It consists of evaluating the aesthetic design of the home page or source, the number and the quality of icons, also includes the aspects related to the ease that the user has to find each of the tools and information of the course as well as the presentation of the contents (Moral \& Villalustre, 2009; Abarca, 2009). On the other hand, Santoveña (2010) mentions that the quality of the presented resources and technical requirements should also be taken into account, as well as the complementary services understood as administrative management, general information, news and agenda of activities and spaces or recreational activities.

The second criteria established is the instructional design. They are framed aspects such as the presentation of the objectives within elements such as study guides and the course information itself; flexibility of the didactic contents (Abarca, 2009), understood as the possibility of using information in different environments; types of individual and collaborative activities proposed, related to the quality of synchronous activities (chats, live videoconferences) and asynchronous (forums, E-mail, Webquest, Weblogs); suitability of activities for the achievement of objectives, understanding as the knowledge construction process; coherence between content, objectives, activities and evaluation; and finally, the forms of evaluation proposed in terms of the modality (formative) and the ways of achieving it (facilitator evaluation, self-evaluation, Co-evaluation) are considered relevant (Colmenares, 2012).

The third criteria is the tutorial action, which involves aspects such as the construction of knowledge from 
previous knowledge; promotion of communication; development of a virtual community (Abarca, 2009); customization of the accompaniment; professor's roles (Santoveña, 2010) that involve pedagogical aspects such as accompanying, guiding, instruct; and operational aspects such as communicating, motivating, evaluating, providing resources and information and giving support (Moral \& Villalustre, 2009; Colmenares, 2012).

The fourth criteria established is the virtual class. It is the nodal point for the participation of the students in the course; This criteria must contain the following key elements: first, a learning path that allows the student to access the information in the times and spaces appropriate to each space (weeks, months or modules); video or written communications in which the tutor or guide of the process is in permanent contact with the student and not only during the first sessions (Abarca, 2009).

\section{Metodology}

Our objective in this study was to analyze educational virtual platforms, where they were initially characterized and then evaluated using different criteria such as: technical design, materials design, instruction design; tutorial action and the virtual class. The methodology used was of a qualitative descriptive type where the synchronous and asynchronous methods of virtual teaching established in each university were applied (Creeswell, 2005).

On the other hand, it is essential to name the universities that were part of this study as well as the educational virtual platforms that were used, as they are presented below:

\begin{tabular}{ll}
\hline University & Academic virtual platform \\
\hline Uniminuto & Moodle platform \\
\hline Tecnologicos de Monterrey & Blackboard platform \\
\hline Universidad del Tolima & Jimdo platform \\
\hline \multicolumn{1}{c}{ Chart 1. Universities and virtual platforms } & Source: González, Villota \& Freire (2018).
\end{tabular}

In relation to the above, it is important to highlight that the evaluation of educational virtual platforms was carried out, taking into account four criteria: technical design, materials design, design of instruction and tutorial action design and virtual class.

\section{Presentation and Discussion of the Results}

For the analysis of the academic virtual platforms, three tables were done in which the characterization and evaluation were done taking into account the aforementioned criteria; that is, writing the different characteristics of the environment in each selected aspect, as well as in the lower categories. It was necessary to represent it in this way because it facilitated making judgments and determining the different aspects related to strengths, but also the weaknesses, threats and opportunities that will allow suggest changes and highlight positive aspects in each learning environment and in general. Next, the evaluation application tables are related to each one of the educational virtual platforms. 
Table 1. Application of the Virtual Classroom Assessment tool in the Moodle Platform

Esthetically the program is simple, basic colors (yellow and blue) and with large

Esthetic design print, the menus are easy to access and obvious at first glance, at first glance you will find the tools and tabs where all the aspects of the course are.

Quantity and quality of the icons

Ease to find the tools

Technical

design

and

materials
Presentation of contents
In the course, at first, it is easy to see small icons that indicate each of the tools, although they are even smaller than the letter of the text. They are showy but it is not easy to identify a tool just by the icon.

The tools of the course are located on the far left of the screen and although they are few (only four) they are very easy to see.

The contents are evidenced somewhat confusingly, in the "activities" tab where they are given in chronological order according to the delivery date. The content is little since it only indicates the information of the course, the activities and the explanation, the objectives and other relevant information; Each activity is programmed and selected from the beginning and can be seen from the first day of the course.

There is no evidence of access to services other than students's mail and the sending of messages to the professor. management

It is clear and well discriminated within each part of the course.

General services

General information

There is a place but no additional

News information is published, only the original information designed for the course.

It is clear, the activity is given, the date and

Activity agenda what each of them consists of, as well as the means of delivery.

Recreational activities Does not apply

The guides are the activities explained step by step with the possibility of access to the basic material immediately.

the objectives

of Guides

It is clear and complete.

Instructional Flexibility of the Possibility of use in design didactic contents another environment

\begin{tabular}{lll}
\hline \multirow{2}{*}{ Activities } & Individual & $\begin{array}{l}\text { There are four individual activities (essays, } \\
\text { reports, course evaluation and debate) }\end{array}$ \\
\cline { 2 - 3 } & Collaborative & $\begin{array}{l}\text { Three collaborative activities were } \\
\text { stipulated (analysis report of learning }\end{array}$ \\
\hline
\end{tabular}




\begin{tabular}{|c|c|c|c|}
\hline & \multirow[b]{3}{*}{ Communication } & & environments) \\
\hline & & Synchronous & $\begin{array}{l}\text { There is no chat within the platform in the } \\
\text { course. }\end{array}$ \\
\hline & & Asynchronous & $\begin{array}{l}\text { There is a general forum and one for each } \\
\text { collaborative activity; as well as the } \\
\text { possibility of sending emails to each } \\
\text { participant and the professor. }\end{array}$ \\
\hline & Evaluation & & $\begin{array}{l}\text { It is given through the delivery of the } \\
\text { assignment and Co-evaluation to the } \\
\text { professor. }\end{array}$ \\
\hline \multirow{5}{*}{ Tutorial } & Constructivist & & $\begin{array}{l}\text { The course in general does not take into } \\
\text { account the previous learning of the } \\
\text { participants since it requires readings. } \\
\text { Although it is necessary that the student has } \\
\text { skills to access and use the course properly. }\end{array}$ \\
\hline & Communication & & $\begin{array}{l}\text { The professor is in weekly communication } \\
\text { to infrom about the activities to be done as } \\
\text { well as to motivate the work within the } \\
\text { stipulated times. }\end{array}$ \\
\hline & $\begin{array}{l}\text { virtual } \\
\text { community } \\
\text { development }\end{array}$ & & $\begin{array}{l}\text { The level of interaction is of an informative } \\
\text { nature and mostly seeks to agree with the } \\
\text { participants. }\end{array}$ \\
\hline & $\begin{array}{l}\text { Personalization of } \\
\text { the tutorial }\end{array}$ & & $\begin{array}{l}\text { The tutorial is personalized since the } \\
\text { professor takes care of each group and } \\
\text { individual in particular when new } \\
\text { developments and questions arise from the } \\
\text { students. }\end{array}$ \\
\hline & Professor's role & & $\begin{array}{l}\text { Guide, motivator, and evaluator. It is the } \\
\text { person who guides in case of technical } \\
\text { difficulties or with the course. }\end{array}$ \\
\hline \multirow[t]{2}{*}{ Virtual class } & $\begin{array}{l}\text { Learning path } \\
\text { (months or weeks } \\
\text { clearly } \\
\text { established) }\end{array}$ & & $\begin{array}{l}\text { It is very clear from the beginning, all the } \\
\text { activities are predefined, with the resources } \\
\text { and the procedures to be executed in the } \\
\text { stipulated time. }\end{array}$ \\
\hline & $\begin{array}{l}\text { Video or written } \\
\text { communication }\end{array}$ & & $\begin{array}{l}\text { It has an introduction in video to each } \\
\text { activity that shows the objective, which it is } \\
\text { only part of the initial information. }\end{array}$ \\
\hline
\end{tabular}

Source: González, Villota \& Freire (2018).

Table 2. Application of the virtual classroom assessment tool in Blackboard

\begin{tabular}{lll}
\hline & Esthetic design & $\begin{array}{l}\text { Esthetically the design is simple, clear and } \\
\text { functional, with white background colors, some } \\
\text { gray tones and mostly black letters. The icons are } \\
\text { simple but clear and visible. }\end{array}$ \\
\cline { 2 - 3 } $\begin{array}{l}\text { Technical } \\
\text { design }\end{array}$ & Quantity and quality of the icons & \begin{tabular}{l} 
The platform is scarce in icons with a tendency to \\
simplicity, little graphic illustration of the icons, \\
and materials they are mostly textual, nevertheless they \\
\cline { 2 - 3 }
\end{tabular} \\
\cline { 2 - 3 } & are clear and visible to the user.
\end{tabular}


Ease to find the tools

Presentation of contents

\begin{tabular}{lll}
\hline & $\begin{array}{l}\text { Administrative } \\
\text { management }\end{array}$ & $\begin{array}{l}\text { The services are monitored and evaluations are } \\
\text { common through surveys that the user answers } \\
\text { about those services. }\end{array}$ \\
\cline { 2 - 3 } $\begin{array}{l}\text { General } \\
\text { services }\end{array}$ & General information & $\begin{array}{l}\text { The information is accessible, accurate, relevant, } \\
\text { clear and sufficient. }\end{array}$ \\
\cline { 2 - 3 } & News & $\begin{array}{l}\text { They are expressed as advertisements and are } \\
\text { visibly on the platform. }\end{array}$
\end{tabular}

Activity agenda

Recreational activities Does not apply

Guides

Presentation of the objectives

Course information

Flexibility of the didactic contents

Possibility of use in another environment

Individual

Instructional design

Activities

Collaborative

Navigation on the platform is easy, it is just a matter of practicing frequently. The distribution of the tools on the platform is described as an attractive technique.

The contents are presented in a clear, specific, relevant manner and with audiovisual resources. There are general announcements of the course and functional communication channels.

With sufficient information, easily accessible, with clear activities, date, necessary resources and the procedure to be followed.

In the icon of the calendar and program you have the description of the activity, the corresponding procedure, the resources you can access to and the deadline.

It is completed, with enough information, easy to access and relevant. There are some didactic design missing.

The contents are downloadable and most of them can be used for other pedagogical environments such as bibliographic references.

There are individual activities such as the commitment or code of ethics, mastery of technological resources, tests, reports and evaluation of the course.

Collaborative activities are stipulated as the course forum, team forum, and sessions for specific topics, group evaluations and team work. In addition, communication channels are made possible among the members of the course through institutional e-mail or internal mail.

\begin{tabular}{lll}
\hline \multirow{2}{*}{ Communication } & Synchronous & There is no chat within the platform. \\
\cline { 2 - 3 } & Asynchronous & $\begin{array}{l}\text { There is a general forum and one for each } \\
\text { collaborative activity; as well as the possibility of } \\
\text { sending emails to each participant and the } \\
\text { professor. }\end{array}$ \\
\hline
\end{tabular}

Evaluation

It is done through the delivery of the assignments and Co-evaluation to the professor.

\section{Constructivist}

The course in general does not take into account the previous learning of the participants.

Tutorial

$$
\text { Communication }
$$


motivate the work within the stipulated times.

\begin{tabular}{ll}
\hline $\begin{array}{l}\text { Virtual } \\
\text { community } \\
\text { development }\end{array}$ & $\begin{array}{l}\text { The level of interactions is of an informative } \\
\text { nature and mostly seeks to agree with the } \\
\text { participants. }\end{array}$ \\
\hline
\end{tabular}

Personalization

of the tutorial

\section{Professor's role}

Learning path

(months or

weeks clearly

Virtual class established)

Video or written

communication
The tutorial is personalized since the professor takes care of each group and each student in particular when new developments and questions arise from the students.

Guide, motivator, and evaluator. It is the person who guides in case of technical difficulties or with the course.

It is very clear from the beginning, all the activities are predefined, with the resources at the user's hand and with the procedures to be executed in the stipulated time.

It has an introduction in video to each activity that shows the objective of it. It is only part of the initial information.

Source: González, Villota \& Freire (2018).

Table 3. Application of the virtual classroom assessment tool in Jimdo

Attractive and very visible page, it presents variety in its form, the menus are easy to access. The information is distributed in such a way that it is

Esthetic design visible and clear to the reader. It is organized in the before and after where you can find activities of the previous semesters and the current ones. It also gives the option to download some text if necessary.

Quantity and quality of the icons It has icons visible to the reader and easily accessible.

The tools are located on the right side of the screen,

Ease to find the tools they are easily accessible and the information provided is relevant according to the selected course. The contents are easily accessible, the information that is required and what is needed is clearly displayed. You have access to a lot of information

Presentation of contents that is diverse and varied. Besides being varied, it presents the activities that must be done by the students enrolled in the courses. The delivery dates for each of the participants are clearly presented.

\begin{tabular}{lll}
\hline \multirow{2}{*}{$\begin{array}{l}\text { Administrative } \\
\text { management }\end{array}$} & $\begin{array}{l}\text { Little, there are only some links for questions. The } \\
\text { professor's email is available to clear doubts. }\end{array}$ \\
\cline { 2 - 3 } General information & $\begin{array}{l}\text { It is clear, relevant, and enough. It is specific in what } \\
\text { to do. }\end{array}$ \\
\cline { 2 - 3 } News & $\begin{array}{l}\text { On the platform the news are expressed as } \\
\text { advertisements and they are on the right side of the } \\
\text { platform (reminders, etc). }\end{array}$ \\
\hline Recreational activities agenda & $\begin{array}{l}\text { It is not clearly identified, however it is located } \\
\text { within each established CCP: Comprehensive } \\
\text { Course Plan. }\end{array}$ \\
\hline $\begin{array}{l}\text { There are some recreational activities on the right } \\
\text { side of the platform. }\end{array}$ \\
\hline
\end{tabular}




\begin{tabular}{|c|c|c|c|}
\hline \multirow{8}{*}{$\begin{array}{l}\text { Instructional } \\
\text { design }\end{array}$} & \multirow{3}{*}{$\begin{array}{l}\text { Presentation of the } \\
\text { objectives } \\
\begin{array}{l}\text { Flexibility of the } \\
\text { didactic contents }\end{array}\end{array}$} & Guides & $\begin{array}{l}\text { Clear and very descriptive, these correspond to each } \\
\text { of the CCPs of each program. }\end{array}$ \\
\hline & & Course information & $\begin{array}{l}\text { There is a lot of information about the courses } \\
\text { established in each program. }\end{array}$ \\
\hline & & $\begin{array}{l}\text { Possibility of use in } \\
\text { another environment }\end{array}$ & It is posible because you can download the files. \\
\hline & \multirow{2}{*}{ Activities } & Individual & $\begin{array}{l}\text { There are some activities to be done but they do not } \\
\text { specify if they are individual or in group. Among } \\
\text { them are: essays, papers, concept maps, summaries. }\end{array}$ \\
\hline & & Collaborative & $\begin{array}{l}\text { Activities are not clear, they are only presented and } \\
\text { agreed during the pedagogical agreement. The } \\
\text { exhibitions are organized according to pedagogical } \\
\text { agreement. }\end{array}$ \\
\hline & \multirow{2}{*}{ Communication } & Synchronous & Does not have any kind of instant communication. \\
\hline & & Asynchronous & $\begin{array}{l}\text { There is a possibility of exchanging information in } \\
\text { different times and spaces. }\end{array}$ \\
\hline & Evaluation & & It has a table of grades and time for tutoring. \\
\hline \multirow{5}{*}{ Tutorial } & Constructivist & & $\begin{array}{l}\text { The tutorials are already planned and scheduled. } \\
\text { However, there is a space called Pedagogical } \\
\text { Agreement where, in agreement with the students, } \\
\text { they define the methodology and the type of } \\
\text { evaluation to be followed. }\end{array}$ \\
\hline & Communication & & $\begin{array}{l}\text { The communication is permanent and accurately on } \\
\text { both sides. }\end{array}$ \\
\hline & $\begin{array}{l}\text { Virtual } \\
\text { community } \\
\text { development }\end{array}$ & & $\begin{array}{l}\text { The level of interactions is of an informative nature } \\
\text { and mostly seeks to agree with the participants. }\end{array}$ \\
\hline & $\begin{array}{l}\text { Personalization of } \\
\text { the tutorial }\end{array}$ & & $\begin{array}{l}\text { The tutorial is aimed at addressing doubts or } \\
\text { concerns that arise throughout the week or the } \\
\text { course. }\end{array}$ \\
\hline & Professor's role & & $\begin{array}{l}\text { Guide, motivator, and evaluator. It is the person who } \\
\text { guides in case of technical difficulties or with the } \\
\text { course. }\end{array}$ \\
\hline \multirow[t]{6}{*}{$\begin{array}{l}\text { Virtual } \\
\text { class }\end{array}$} & $\begin{array}{l}\text { Learning path } \\
\text { (months or weeks } \\
\text { clearly } \\
\text { established) }\end{array}$ & & $\begin{array}{l}\text { The orientation of the course is planned by tutorials } \\
\text { according to the estimated time for the course. }\end{array}$ \\
\hline & $\begin{array}{l}\text { Video or written } \\
\text { communication }\end{array}$ & & $\begin{array}{l}\text { There is a fairly high percentage of videos provided } \\
\text { to strengthen the themes scheduled each week. }\end{array}$ \\
\hline & Communication & & $\begin{array}{l}\text { The communication is permanent and accurately on } \\
\text { both sides. }\end{array}$ \\
\hline & $\begin{array}{l}\text { Virtual } \\
\text { community } \\
\text { development }\end{array}$ & & $\begin{array}{l}\text { The level of interactions is of an informative nature } \\
\text { and mostly seeks to agree with the participants. }\end{array}$ \\
\hline & $\begin{array}{l}\text { Personalization of } \\
\text { the tutorial }\end{array}$ & & $\begin{array}{l}\text { The tutorial is aimed at addressing doubts or } \\
\text { concerns that arise throughout the week or the } \\
\text { course. }\end{array}$ \\
\hline & Professor's role & & $\begin{array}{l}\text { Guide, motivator, and evaluator. It is the person who } \\
\text { guides in case of technical difficulties or with the } \\
\text { course. }\end{array}$ \\
\hline $\begin{array}{l}\text { Virtual } \\
\text { class }\end{array}$ & $\begin{array}{l}\text { Learning path } \\
\text { (months or weeks } \\
\text { clearly }\end{array}$ & & $\begin{array}{l}\text { The orientation of the course is planned by tutorials } \\
\text { according to the estimated time for the course. }\end{array}$ \\
\hline
\end{tabular}




\begin{tabular}{ll}
\hline established) & \\
\hline $\begin{array}{l}\text { Video or written } \\
\text { communication }\end{array}$ & $\begin{array}{l}\text { There is a fairly high percentage of videos provided } \\
\text { to strengthen the themes scheduled each week. }\end{array}$ \\
\hline
\end{tabular}

Source: González, Villota \& Freire (2018).

In relation to the above, the evaluation criteria focused on the academic virtual platforms mentioned above are determined as follows:

\subsection{Technical Design and Materials}

In this aspect it is evident that the information presented is easily visible, clear and esthetically pleasing; the presentation of the icons is difficult to visualize in two of the platforms, but in the other one it is very easy to see and use; the tools of the course are simple to find in all three platforms. Regarding the presentation of the contents, clarity, relevance and audiovisual resources were generally noted in them, in addition to the delivery date of the activities. The complementary services are manifested in surveys to users regarding levels of satisfaction of the course design and tutorial action, messages to the professor, course information, platform announcements and very few recreational activities (only in one of the platforms activities of this type are proposed).

\subsection{Instructional Design}

The objectives are clearly and completely demonstrated in the three virtual platforms within the presentation of the course information, as well as in the development of the learning guides and activities of the course. The resources can be used in other platforms because they are portable and accessible from devices such as tablets or cell phones with Internet access. The activities in two of the courses are clearly discriminated as group or individual, in one of them they are given by pedagogical agreement and in general they are essays, reports, test type evaluations and forums. Regarding synchronous communication, it does not exist within the course in any of the platforms, it has the e-mail and the forum for each activity. The evaluation is given through the professor's feedback and test-type questionnaires.

\subsection{Tutorial action}

In two of the courses it is evident that the students' previous learning is not taken into account due to the fact that readings and reports based on given information must be made (although the student needs previous skills), in one of the environments a pedagogical agreement is given in which methodologies and agreed evaluation are defined. The communication is weekly and constant in case of problems with the students or clarifications. The type of communication seeks to inform students and not the creation of a learning community based on arguments. Regarding the tutorials of the professor, personalized attention is shown to each participant according to the questions raised. The roles of the professor are in general guiding, motivating, evaluating and is who guides in case of technical difficulties or with the course.

\subsection{Virtual class}

The activities (learning path) are described from the beginning of the course in two of the platforms, in one of them is given by agreements at the beginning of it. The audiovisual communication is evident for each activity but during the courses it is not renewed or fed with this type of tools.

\section{Conclusions}

The virtual educational platforms are innovative scenarios in the teaching and learning process since they are "new" elements that the teacher must integrate in practice, thus generating strengthening in the student's learning. However, the implementation of educational virtual platforms as scenarios of innovation leads us to recognize that these are means and not purposes for the learning of different contents linked to the course plans; that is, they are mediating tools.

Thus, the weaknesses found are in the design of educational virtual platforms, being simple, it lacks from more educational and pleasant illustration. Although the tutorials by the professors of the course are interesting, they can be improved integrating strategies that allow the professor to be more directly involved with the user, it does not contain interactive activities that can be learned online. Resources that can support the consolidation of content are left aside. Forums are used as non-academic communication tools and their academic use is blurred. There is no communication in video, audio or any other from the one written. The design of the forum in Moodle does not handle a hierarchical order as it happens in Blackboard, which prevents to keep an order in the 
conversation easily.

The opportunities are related to the fact that with the technological advances in information and communication there will always be the possibility of innovation in the platforms, the amount of external diverse information can be exploited by the environment for power learning and the tools of synchronous communication can be used as support tools in the learning process, among them the use of Skype, Gmail chat, social networks, wikis such as Google Drive, Applets, interactive games among others.

Among the threats found is the insecurity of the personal data of each user, the possibility of fraud in the activities and academic work as well as the impersonation of unethical students in the process. Another aspect that often happens is the errors presented in the servers or service providers of the platform, but also failures in the times by the professors or facilitators that prevent the feedback of the activities done by the students. The lack of experience on the part of the users could cause errors in the feedback of the activities and generate demotivation in the students, as well as the lack of clear rules regarding the use of the communication tools and language to be used.

The three learning environments presented in this document, when evaluated, conclude that they are relevant in many of the elements proposed as evaluation criteria, specifically in aspects such as the presentation of the course, the presentation of the information, the definition of the learning path, feedback by the professor. This allows us to affirm that this is a space in which the student can feel comfortable and close (Díaz, 2005). But it is also a tool designed for virtual interaction that opens the door to the future.

The learning environments could be improved if elements such as the most direct interaction of the professor, improvement in the designs and esthetics of some environments, and communication tools such as chat, videoconference, and wikis are taken into account; although this could be treated through the use of applications and programs easily accessible and recognized as Google Drive, Skype and other tools present on the Web.

\section{Referencias}

Abarca, F. R. (2009). Propuesta para evaluar aprendizajes virtuales. Universidad Católica de santa María. Recuperado de http://www.ucsm.edu.pe/rabarcaf/PropEvalAprVirt.pdf

Berdugo, T. M., Pedraza, A. N. (2007). Evaluación de Lingweb: ambiente virtual para el aprendizaje de lenguas. Revista Lenguaje de la Universidad del Valle, 36(2), 473-504.

Biggs, J. (2005). Calidad del aprendizaje Universitario. Madrid, España: Narcea.

Bustos, S. A., \& Coll, S. C. (2010). Los entornos virtuales como espacios de enseñanza y aprendizaje, una perspectiva psicoeducativa para su caracterización y análisis. Revista mexicana de investigación educative, 15(4), 163-184.

Colmenares. A. M. (2012). Los aprendizajes en entornos virtuales evaluados bajo la concepción formadora. Revista electrónica interuniversitaria de formación del profesorado, 15(1), 125-134.

Chacin, M (2003). La evaluación Virtual en la Práctica. Universidad Na-cional Experimental Simón Rodríguez. Venezuela. [En Red]. Consultado: Abril, 9, 2006. Disponible en: http://www.ucv.ve/edutec/Ponencias/69.doc en abril de 2006

Díaz, B. F. (2005). Principios de diseño instruccional de entornos de aprendizaje apoyados con TIC: un marco de referencia sociocultural y situado. Instituto Latinoamericano de la comunicación educativa. Recuperado de $\mathrm{http} / / /$ investigacion.ilce.edu.mx/tyce/41/art1.pdf

Elola N. y Toranzos, L. (2000). Evaluación Educativa: una aproximación conceptual. Buenos Aires. [En Red]. Consultado: Abril, 9, 2006. Disponible en: http://www.oei.es/calidad2/luis2.pdf

Enriquez, J. A. V., De Oliveira, A. M. P., \& Valencia, H. G. (2017). What Mathematic Teachers Say about the Teaching Strategies in the Implementation of Tasks. English Language Teaching, 11(1), 65. https://doi.org/10.5539/elt.v11n1p65

Enríquez, J. A. V., \& Enríquez, M. D. V. (2018). Estratégias de ensino para a construção de produtos tecnológicos mediantes a implementação de resíduos sólidos (p. 113; 128). Em: Educação no século XXI. Editorial: Poisson.Belo Horizonte, Brasil.

González, H. (2015). La integración de la tecnología como herramienta significativa en la enseñanza del inglés como lengua extranjera. Revista Horizontes Pedagógicos, 17(1), 53-66.

Henao, O. (2003): La red como medio de enseñanza y aprendizaje en la educación superior. [En Red]. http://www.colegiovirtual.org/pr03_14.html 
Hughes J. y Graham A. (2003). A Framework for the Evaluation of E-Learning. En Know Net, European Seminars. [En Red]. Consultado: Abril, 2006. Disponible en: http://www.theknownet.com/ict_smes_seminars/pa-pers/Hughes_Attwell.html

Maenza, R (2006). Indicadores de evaluación para plataformas virtuales empleadas en educación. III Congreso ONLINE OCS. Observatorio para la Cibersociedad- Disponible en http://www.cibersociedad.net/ congres2006. Consultado en Diciembre, 2008

Marqués. G. P. (2003). Tipos de páginas web aplicables en educación. Diseño de páginas WEB educativas. Recuperado de http://www.peremarques.net/disdesaw.htm

Méndez, G (2008): La tecnología tiene el potencial de transformar la educación. Entrevista a Ralph Young, vicepresidente mundial de asuntos públicos de Microsoft. Periódico El Universal. Venezuela. Edición $\begin{array}{llllll}\text { Domingo } & 7 & \text { de } & \text { Diciembre, } & \text { Disponible } & \text { en }\end{array}$ http://www.eluniversal.com/2008/12/07/eco_art_latecnologiatiene_1175564.shtml

.Moral, P. M., \& Villalustre, M. L. (2009). Evaluación de prácticas docentes universitarias desarrolladas en entornos virtuales. Pixel-Bit Revista de medios y educación, 2009 (34), 151-163.

Peña, S. M., Avendaño, P. B. (2006). Evaluación de la implementación del aula virtual en una institución de educación superior. Suma Psicológica, 13(2), 173-192.

Rivas, N. M. (2000). Innovación Educativa: Teoría, procesos y estrategias. Madrid, España: Síntesis.

Santoveña, C. S. (2005). Criterios de calidad para la evaluación de los cursos virtuales. Eticanet, 2(4). Recuperado de http://tecnologiaedu.us.es/nweb/htm/pdf/calidad.pdf

Santoveña. C. S. (2010). Cuestionario de evaluación de la calidad de los cursos virtuales de la UNED. Revista $\begin{array}{llllll}\text { Educativa } & a & \text { Distancia } & \text { RED. 2010(25). } & \text { 1-22. Tomado }\end{array}$ http://www.redalyc.org/articulo.oa?id=54717071003

Valencia, H. G., Enriquez, J. A. V., \& Agredo, P. M. (2017). Strategies Used by Professors through Virtual Educational Platforms in Face-To-Face Classes: A View from the Chamilo Platform. English Language Teaching, 10(8), 1. https://doi.org/10.5539/elt.v10n8p1

Valencia, H. G., Enriquez, J. A. V., \& Acosta, L. R. (2018). The Education of an English Professor: The Biographical Narrative. English Language Teaching, 11(4), 101. https://doi.org/10.5539/elt.v11n4p101

\section{Copyrights}

Copyright for this article is retained by the author(s), with first publication rights granted to the journal.

This is an open-access article distributed under the terms and conditions of the Creative Commons Attribution license (http://creativecommons.org/licenses/by/4.0/). 